\title{
The Role of The State Government In Managing and Preserving The Sasi Administration In The State of The Haruku
}

\author{
Sostones Y Sisinaru ${ }^{1}$ \\ \{onesnesto@yahoo.com ${ }^{1}$ \} \\ Faculty of Law Universitas Pattimura, Ambon, Indonesia ${ }^{1}$
}

\begin{abstract}
Customary law is a legal system known in the social life environment in Indonesia and other countries. Indonesia consisting of various islands and regions scattered from Sabang to Maroke from Mimar Island to Rote Island with so many cultures and customs. One of the local wisdom of the people of Maluku is Sasi lompa is a sanction for the community in terms of preserving the environment and an appropriate ecosystem and alera life alalam. This type of research is empirical juridical research, this research was conducted in Central Maluku District, Negeri Haruku Sameth. Sources of data used in this study ie primary data and secondary data, data collection techniques conducted by interview and document studies. The problematic role of the Government of the State in making a State Regulation in protecting certain ecosystems that become the value of local wisdom and economic value for the life of the community.
\end{abstract}

Keywords: Customary law; sasi lompa; state regulation.

\section{Introduction}

The law of a country as an equivalent which is defined as a system of behavior in regulating human beings is a form of coercion. This means that all the order reacts to certain events, which are considered as something that is not desirable because it is detrimental to society and can provide a certainty of something abstract [1]. John Austin, quoted by Soerjono Soekanto [2] argues that the law is an order from those who hold the highest power or who hold sovereignty. According to Austin, law is what is charged to regulate thinking beings, which commands are carried out by thinking beings who hold and have power. In addition to the legal authority as outlined in the introduction, in addition to the legal authority, the need for institutionalization of law in the community is to enforce the law as part of a series of processes which include law making, law enforcement, justice and justice administration. Customary law is a legal system that is known in the environment of social life in Indonesia and other countries. The source of customary law is unwritten legal regulations that grow and develop and are maintained with the legal awareness of the community. These regulations are not written and are growing, so customary law has the ability to adjust and elastic.

The term customary law was first introduced scientifically by C. Snouck Hurgronje, then in 1893, C. Snouck Hurgronje in his book entitled "De Atjehers" mentions the term customary law as the custom of recht (Dutch) which is to name a control system social (social control) living in Indonesian society. This term was then developed scientifically by Cornelis van 
Vollenhoven who was known as a Customary Law expert in the Dutch East Indies (before becoming Indonesia).

Cornelis van Vollenhoven was the first to launch the idea of the division of customary law. According to him, the regions in the archipelago according to customary law can be divided into the following 23 customary environments: Aceh, Gayo and Batak, Nias and surrounding areas, Minangkabau, Mentawai, South Sumatra, Enggano, Melayu, Bangka and Belitung, Kalimantan (Dayak), Sangihe-Talaud, Gorontalo, Toraja, South Sulawesi (Bugis / Makassar), North Maluku, Maluku Ambon, Southeast Maluku, Papua, Nusa Tenggara and Timor, Bali and Lombok, Java and Madura (Coastal Java), Java Mataraman, and West Java (Sunda), while according Gerzt states that Indonesian people have 350 cultures, 250 languages and all beliefs and religions in the world are in Indonesia. The recognition of the Indonesian government against customary law has been manifested in words that become a sentence and implied in the constitution as stipulated in the 1945 Constitution of the Republic of Indonesia Article 18B paragraph (2).

Culture is regulating so that people can understand how they should act, act, determine their attitude if they relate to other people. Edward Burnett Tylor, culture is a complex whole, which contains knowledge, beliefs, art, morals, laws, customs, and other abilities acquired by a person as a member of society. The purpose of cultural preservation is also to revitalize culture (strengthening). Regarding cultural revitalization. A. Chaedar Alwasilah said there were three steps, namely: (1) understanding to raise awareness, (2) collective planning, and (2) generating cultural creativity.

The implementation of the sasi in the Haruku area, which in the original language was called "Sasi Aman Haru-Ukui". Historically based on historical stories, the implementation of this sasi began in the 1600s. The implementation of this sasi is related to the enormous natural potential in Haruku, and to safeguard and preserve and maintain all the natural resource potential contained in Haruku. The implementation process of sasi is aimed at preserving nature and its wealth both on land but also at sea. Sasi lompa is a source of one of the marine resources, namely sasi against jumping fish which has been banned by customary law to catch if the sasi has not been opened. The process of opening the sasi was marked by the beating of Tifa by Kewang as a sign of opening, then the first stocking of the nets by the King and the pastor of the sasi was opened, then only by all the residents were they free to catch the fish of lompa.

Based on the above description, the writer raises the problem to be examined are: How is the role of the State Government in shaping the state regulation in preserving sasi lompa in the state of Haruku? The purpose of this paper is to examine the role of the Regional Government in the provision of regulating legal instruments related to sasi lompa on my island.

\section{Research Method}

This type of research is empirical juridical research, the empirical legal research that was investigated initially was secondary data which was then continued with research on primary data in the field. This research was conducted in Central Maluku District, Haruku - Sameth State. The source of data used in this study is primary data and secondary data, primary data is done to obtain field data by conducting interviews directly with informants. Secondary data is done to obtain library data sourced from legal materials consisting of: Primary Legal Material, namely legal material that becomes the basic basis that has a binding nature, in the form of 
applicable legislation governing related issues in this study . Secondary legal material, it is needed materials in the form of books, scientific papers and seminar results that are relevant to this research, tertiary legal materials or supporting legal materials that include materials that give instructions and explanations of primary, secondary legal materials such as general dictionaries, legal dictionary, which is relevant and can be used to supplement the data needed in this study.

Data collection techniques are carried out by direct interviewing the field by asking questions directly to the resource person to obtain the necessary data related to the problem. Document study is carried out to obtain secondary data, by collecting library material or other data sources. In addition, it records the quotes and reviews of the theories and legislation relating to the object of research. The technique of analyzing data collected through research was analyzed with qualitative descriptive methods, namely by analyzing data obtained from primary and secondary data sources. After that a thorough discussion was carried out, and based on the discussion a conclusion was taken as an answer to the problem under study.

\section{Result and Discussion}

\subsection{Overview of Indonesian Customary Law}

Customary law is one form of law that still exists / exists in the life of indigenous peoples in Indonesia. We also need to know that Customary Law is one form of law that applies in the life and legal culture of Indonesian society that is still valid today. We can see the existence of customary law until now through the existence of customary courts and customary law instruments that are still maintained by indigenous and tribal peoples in Indonesia to resolve various disputes and offenses that cannot be handled by police, courts, and correctional institutions. Customary law is retained today by indigenous and tribal peoples because they believe that decisions issued through customary courts against an offense that are tried through them can provide a sense of justice, and a return to balance in the lives of indigenous peoples over the spiritual shock of the adat offense.

The existence of customary law as a form of law that is recognized for its existence in the life and legal culture of the Indonesian people is contained in the 1945 Constitution of the Republic of Indonesia or for the brevity of the 1945 Constitution, namely Article 18B paragraph (2) which determines "the State recognizes and respects unity - Customary Law Society and their traditional rights as long as they are alive and in accordance with the development of society and the principle of the Republic of Indonesia State Ksatuam, which is regulated in the law ". An explanation of the recognition of customary law by the State is also contained in Article 27 paragraph (1) of the Constitution which stipulates "All citizens together with their position in law and government and are obliged to uphold the law and government with no exception", from which the provisions can concluded that both civilians and government officials are obliged to uphold the laws that apply in the life and legal culture of Indonesian society, including criminal law, civil law and customary law.

Customary law as a positive law has distinctive characteristics, namely; customary law is a law that is largely unwritten, but its values exist and apply in the lives of indigenous peoples who enforce the customary law. Customary law applies in a limited scope, that is, only I am in an indigenous community where the customary law lives or resides, and this situation allows that each indigenous community can have customary laws that differ from one another. We can find further information on customary law in the opinion expressed by Soekanto as a 
jurist, in which he defined customary law as "a complex of customs which are mostly not scripted, not codified and coercive having sanctions, so having legal consequences. One subsection contained in customary law is customary law delik (adat delicten recht) or also known as customary criminal law. We can find an understanding of the term customary criminal law through the opinion of Hilman Hadikusuma, who argued that the term customary criminal law is a translation of the Dutch term "adat delicten recht" or "customary violation law" [3], and he also stated that these terms were not known among culture. Customary criminal law generally contains legal rules which are not written in nature but have legal consequences for anyone who violates the law, within the customary law area applies [4].

\subsection{Role of Local Government in Maintaining and Preserving Local Wisdom}

The government is an organization that has the power to create and implement laws in certain regions. According to Suradinata, the government is an organization that has great power in a country, including community affairs, territorial affairs and power affairs in order to achieve the goals of the country.

Inu Kencana Syafi'e (2009) writes that the term government comes from the root of the command which then gets affix (peers). If the command word gets a prefix, then the word government is nothing but an elite body or organ that does the work of regulating and managing in a country [5]. And if the word government gets an ending, the word government means the matter, the way, the act, or the affairs of the ruling and legitimated body which in some basic words there are several elements, namely [6]:

- There are those who govern (the Government) and those who are governed (the People).

- The governing party has the authority and legitimacy to regulate and manage the people.

- The party ordered is obliged to obey the legitimate government.

- There is a reciprocal relationship between parties that govern and those that are governed have a reciprocal relationship vertically or horizontally.

According to W.S Sayre in Inu Kencana (2009) the government is an organization of the state, which shows and exercises its power. While Wilson said that the government is an organization of strength, not always associated with the organization of the armed forces, but two or a group of people from many groups of people prepared by an organization to realize their goals and objectives, with matters that provide information for the affairs general public affairs [7].

The administration of government in Indonesia consists of the Central Government and Regional Governments. This is contained in the fourth amendment to the Constitution of the Republic of Indonesia which states that the Republic of Indonesia is in the form of a unitary state with the principle of broad regional autonomy. The territory is divided into provinces. In Chapter I of Law Number 32 of 2004 concerning Regional Government, Article 1 paragraph (1) states that: The central government, hereinafter referred to as the government, is the President of the Republic of Indonesia which holds the power of the government of the Republic of Indonesia as referred to in the basic Law of the Republic of Indonesia Indonesia in 1945. Whereas in paragraph (2) it is stated that: The Regional Government is the organizer of government affairs by the regional government and the DPRD according to the principle of autonomy and the duty of assistance with the principle of autonomy to the greatest possible extent in the system and principles of the Unitary Republic of Indonesia as referred to in the Basic Law State of the Republic of Indonesia in 1945 [8]. Still in Chapter I Article 1 Paragraph (3) of Law Number 32 of 2004 states that Regional Governments are Governors, 
Regents or mayors, and regional apparatuses as elements of regional government administrators.

In the 1945 Constitution, the results of the amendment in Chapter VI Article 18 paragraph 3 said that the provincial, regency, and municipal governments have the Regional People's Legislative Assembly, whose members are elected through general elections. Furthermore, regarding the provincial, regency, and city administrations, it was also stated that, Governors, Regents and Mayors were respectively heads of provincial, regency and city governments. In other words, regional government is a device of the government in the region along with the Regional Parliament. So, the provincial level is the Governor and the Provincial DPRD. While the regency/city government is the regent / mayor along with the regency/city DPRD [9].

The Regional Government is authorized to regulate and administer its own government affairs according to the principle of autonomy and co-administration. The granting of broad autonomy to the regions is intended to accelerate the realization of public welfare through improved services, empowerment, and the participation of the wider community. Through this broad autonomy, regions are also expected to be able to improve competitiveness while still paying attention to the principles of democracy, equity, justice, privileges and specificities as well as the potential and diversity of the regions within the Unitary State of the Republic of Indonesia system. In accordance with the mandate of the Law of the Republic of Indonesia Number 32 of 2004 which has been amended by Law Number 23 of 2014 concerning Regional Government, the Regional Government in order to increase the effectiveness of the implementation of regional autonomy must pay attention to the relations between the composition of government structures and between regional governments, regional potential and diversity. Aspects of the relationship of authority pay attention to the specificity and diversity of regions in the system of the Unitary State of the Republic of Indonesia. Aspects of financial relations, public services, utilization of natural resources and other resources are carried out fairly and in harmony. In order to be able to carry out its role, the regions are given the widest authority accompanied by the granting of rights and obligations to carry out regional autonomy in the principle of the unity of the government administration system. In general, the authority of regional government covers all matters in the field of government, except for matters that are the authority of the central government. Local government authority, according to Law Number. 32 of 2004 which has been amended by Law Number 23 of 2014 concerning Regional Government, there are mandatory and non-optional authorities.

Mandatory authority means that covers all government affairs at the regional level. While the authority that is optional is to cover all government affairs that actually exist and can improve the welfare of the local community in accordance with the conditions and characteristics of each. The Regional Government Authority that is Compulsory according to Law Number 32 of 2004 which has been discussed with Law 23 of 2014 concerning Regional Government is stated as follows [10]:

- Protecting the community, maintaining unity, national unity and harmony, and the integrity of the Unitary State of the Republic of Indonesia;

- Improve the quality of people's lives;

- Develop a democratic life;

- Realizing justice and equity;

- Improve basic education services;

- Providing health care facilities;

- Providing appropriate social facilities and public facilities,

- Develop a social security system;

- Develop regional planning and spatial planning; 
- Develop productive resources in the area;

- Preserving the environment;

- Managing population administration;

- Conserving socio-cultural values;

- Establish and apply legislation in accordance with its authority; and

- Other obligations stipulated in the legislation.

Indonesia as the country that has the most archipelago from small to large, and the advantages where the country consists of various kinds of diversity of indigenous peoples and has its own characteristics.

It is appropriate that the existence of indigenous groups scattered throughout the Indonesian archipelago and in every province should be something to be proud of, this happens because the existence of indigenous peoples is a nation's wealth and can be a separate source of input for the Indonesian people. Good wealth that can generate income for the state as well as a source of knowledge for researchers from across the continent, which is clearly where one of the benefits of the existence of indigenous peoples is a contribution that can be given to the Indonesian people. Unlike some Asian or European countries that often only have one indigenous community and usually the indigenous people even as a forerunner of the country, such as American or Aboriginal Indian tribes in Australia, which has been marginalized lately.

Indigenous peoples are key to climate change issues. As inhabitants of land and sea, they are very vulnerable to the effects of climate change. Their region is often the target of largescale industries that cause climate change. Whereas it has become common knowledge that their local wisdom helps reduce climate change and provides inspiration for humans in the face of the climate crisis.

\section{Conclusion}

The challenge faced by the community at this time especially the specific village community is the economic problem and a written instrument that can provide absolute certainty regarding the authority to open and close the sasi lompa in my village. This makes people more difficult to preserve the local chaos we know with Sasi Lompa, due to a lack of understanding of local wisdom (Sasi Lompa) it makes the community in carrying out its activities ignores cultural values which are relics that must be cared for and guarded as a result of which tourist spots are converted into locations or places that are damaged by the actual characteristics. The government in this case the local government up to the village government is a unified system that is inseparable from the indigenous peoples and is involved until the things that are directly related to the joints of the custom itself by the government are to play its role. Based on the research conducted, it is recommended that it is necessary to establish a State Regulation to regulate the authority to open and close the Sasi lompa. For the Government and the public to share the results of the sasi lompa fairly and also state egulation in Tourism Management. 


\section{References}

[1] Supriyady, "Position of Customary Law in Historical Paths", Addin, vol. 2 no. January 1-July 2008.

[2] Soekanto, Reviewing Indonesian Customary Law, Third Edition, CV. Rajawali, Jakarta 1985.

[3] H. Hadikusuma, Customary Law, First Printing, Alumni, Bandung 1979.

[4] H. Hadikusuma, Introduction to Indonesian Customary Law (Bandung CV Mandar Maju).

[5] D. Samosir, Indonesian Customary Law. Medan; CV. Nuansa Aulia, 2013.

[6] Abass, Mediation in the Perspective of Sharia Law, Customary Law, and National Law, Kencana Prenada Media Group 2009.

[7] A. Soehardi, Luas and the contents of Social Law, Yayasan Kanisius, 1962.

[8] B. Manan, "Provincial, District and City Authority in the Framework of Regional Autonomy", National Seminar, Faculty of Law Unpad, Bandung, 2000.

[9] F. Kerlinger, in Landung R Simatupang, Principles of Behavioral Research, Yogyakarta, Gadja Mada Press University, 2003.

[10] P. Cruz, Comparison of Legal Systems, Nusa Media, Bandung, 2010. 